NBER WORKING PAPER SERIES

\title{
PRODUCTIVITY GROWTH AND THE REGIONAL DYNAMICS OF ANTEBELLUM SOUTHERN DEVELOPMENT
}

\author{
Alan L. Olmstead \\ Paul W. Rhode \\ Working Paper 16494 \\ http://www.nber.org/papers/w16494 \\ NATIONAL BUREAU OF ECONOMIC RESEARCH \\ 1050 Massachusetts Avenue \\ Cambridge, MA 02138 \\ October 2010
}

We have benefited from data graciously provided by Lee Craig, Michael Haines, and Thomas Weiss and the helpful comments of Stanley Engerman, Price Fishback, Joshua Rosenbloom, David Weiman, Thomas Weiss, and Gavin Wright. This research has been supported by NSF SES-0550913, SES-0551130 The views expressed herein are those of the authors and do not necessarily reflect the views of the National Bureau of Economic Research.

NBER working papers are circulated for discussion and comment purposes. They have not been peerreviewed or been subject to the review by the NBER Board of Directors that accompanies official NBER publications.

(C) 2010 by Alan L. Olmstead and Paul W. Rhode. All rights reserved. Short sections of text, not to exceed two paragraphs, may be quoted without explicit permission provided that full credit, including (C) notice, is given to the source. 
Productivity Growth and the Regional Dynamics of Antebellum Southern Development Alan L. Olmstead and Paul W. Rhode

NBER Working Paper No. 16494

October 2010

JEL No. N11,O13,O31

\title{
ABSTRACT
}

Between 1800 and 1860, the United States became the preeminent world supplier of cotton as output increased sixty-fold. Technological changes, including the introduction of improved cotton varieties, contributed significantly to this growth. Measured output per worker in the cotton sector rose four-fold and large regional differences emerged. By 1840, output per worker in the New South was twice that in the Old South. The economy-wide increase is explained, in equal measure, by growth in output per worker at fixed locations and by the reallocation of labor across regions. These results offer a new view on the dynamics of economic development in antebellum America.

\author{
Alan L. Olmstead \\ Institute of Governmental Affairs \\ UC, Davis \\ Davis, CA 95616 \\ alolmstead@ucdavis.edu \\ Paul W. Rhode \\ Economics Department \\ University of Michigan \\ 205 Lorch Hall \\ 611 Tappan St. \\ Ann Arbor, MI 48109-1220 \\ and NBER \\ pwrhode@umich.edu
}


After a long absence, slavery has recently reclaimed a place in the limelight of American economic history research. Gavin Wright's Slavery and American Economic Development (2006), Stanley Engerman's Slavery, Emancipation, and Freedom (2007), Robert Fogel's The Slavery Debates (2003), and several contributions in Slavery in the Development of the Americas (Eltis, Lewis, and Sokoloff 2004) have all enriched our understanding of the "Peculiar Institution.”

Much of this recent literature synthesizes and reinterprets existing evidence with the aim of providing perspective and even closing long-standing debates about the efficiency of slave plantation agriculture. Such thoughts of closure are premature. We present new data that provide a fresh perspective on plantation efficiency and the dynamics of southern agriculture. These findings complement our previous research, which showed that the creation and diffusion of easier-to-pick, higher-yielding, and superior-quality cotton varieties changed the face of southern farming by significantly increasing labor productivity and improving the South's position in world markets (Olmstead and Rhode 2008a, pp. 107-114; Olmstead and Rhode 2008b).

Here we focus on understanding how the productivity revolution affected the western movement of cotton production and how western movement in turn affected plantation productivity in the antebellum years. We first review the evidence for a biological revolution in cotton production beginning around 1806 . We next offer a critical analysis of how the cliometrics mainstream explained the growth in cotton output and treated the issues of plantation and slave productivity. This literature simply missed the importance of technological change 
even though many traditional historians and pioneering cliometricians had pointed the way. To provide a fresh insight, we present new data on the bales of cotton produced per worker, by region for the decades between 1800 and 1860, and by county for the census years 1839, 1849, and 1859. This evidence reinforces our previously published findings on the growth of picking efficiency suggesting that, while output per worker advanced everywhere, the improvements were most rapid in the New South. Allowing for regionally biased technological innovation enhances the importance of western settlement in explaining the increase in cotton output and revises the understanding of the impact of settlement on planters in the Old South.

\section{The Biological Revolution in Cotton Production}

The improvement of cotton varieties had great significance for the geographical expansion of cotton production and on southern economic development more generally. Biological innovation is a key to understanding the growth in southern productivity and the region's growing preeminence in the world cotton market. Many have decried the lack of indigenous technological advances in the antebellum South, but the region was the undisputed world leader in the creation and diffusion of new, superior cotton varieties. Most of the technologies were developed in the Mississippi Valley and were better suited for the geoclimatic conditions found there than for the conditions common to much of Georgia and the Carolinas, let alone conditions in India and Africa. These findings help explain interregional differences in

production and productivity growth, the extent of the interregional slave trade, and the traditional static comparisons of plantation and non-plantation efficiency.

Southern farmers developed a progression of improved cotton varieties. Around 1800, new green seed cotton varieties boosted southern productivity. But the most important break 
occurred in 1806 when a Mississippi planter and diplomat, Walter Burling, returned from Mexico City with seeds from some unusually appealing cotton plants. This set in motion a chain of events that would revolutionize southern history and profoundly affect the lives of American slaves. Burling shared his discovery with neighboring planters who over the next several decades perfected the Mexican-style cottons to thrive in the Mississippi Valley. This often involved outcrossing the Mexican imports with local cottons and many generations of careful selection to obtain desirable traits. Agronomists regard many of these early creations as the founding stock of several of the major cotton types, which would become popular in the South over the next century. One of the earliest and most widely adopted varieties was Petit Gulf, which gained prominence by the mid-1830s. Most of the breeding innovations occurred on large southwestern plantations, and the varieties developed were most productive in the soils and climates where they were bred. This had an enormous implication for southern development. From the mid1820s through at least the mid-1830s there was a distinct difference between the types of cotton grown in the lower Mississippi Valley and the Southeast. The new western cottons produced higher yields, were of superior quality, were more pest resistant, offered higher lint-to-seed ratios, fetched higher prices, and were significantly easier to pick (Watkins 1908, p. 13; Ware 1950, p. 659). The spread of the new varieties widened the yield and picking efficiency differences that separated the black prairie, brown loam, and alluvial soils of the New South from the poorer lands in the Old South.

In our previous research we employed a sample of over 700,000 individual cottonpicking entries on 142 plantations over 509 plantation years to track the average amount of cotton picked per slave per day in the 60 years preceding the Civil War. Figure 1 graphs the picking indices (based on a specification utilizing quadratic time trends) for the total sample, for 
the Old South, and for the New South. In addition, it presents a new weighted index combining the Old and New South indices using output shares for each region. ${ }^{1}$ The All South index based on the total sample shows a quadrupling of the daily picking rates between 1800 and 1862, with a growth rate of 2.3 percent per annum. The weighted index shows a somewhat smaller overall increase, with a still-robust growth rate of 2.0 percent per annum. The weighted index also suggests the change was more evenly spread across the antebellum era.

Figure 1 also highlights the important regional differences in picking rates. In 1811, when data for both regions first become available, estimated picking rates were 39 pounds per day in the Old South and 42 pounds per day in the New South. The gap was about 9 percent. Over the antebellum era, the gap widened substantially. By 1861, pickers in the New South on average harvested 126 pounds in a day compared to 83 pounds for their counterparts in the Old South, implying a gap of about 51 percent. The growth in picking rates in the Old South was roughly linear in time, whereas growth in the New South was rapid in the 1820s and 1830s and then slowed. As a result, the regional picking rate gap in 1840 reached 81 percent, with the average slave in the New South gathering about 111 pounds per day compared to just 61 pounds in the Old South. Contemporaries credited the overall increase in picking rates to the diffusion of new cotton varieties and saw the regional differences in picking efficiency as a product of the

\footnotetext{
${ }^{1}$ We follow the convention of defining the Old South as including the members of the original 13 colonies (Georgia, North Carolina, South Carolina, and Virginia) and the New South as those states entering the Union after independence (Alabama, Arkansas, Louisiana, Mississippi, Tennessee, and Texas). The one exception is that Florida is treated as a part of the Old South.

The weighted index is calculated as $\mathrm{W}_{t}=1 /\left[\theta_{t} / \mathrm{OS}_{t}+\left(1-\theta_{t}\right) / \mathrm{NS}_{t}\right]$, where $\theta_{t}$ is the Old South output weight

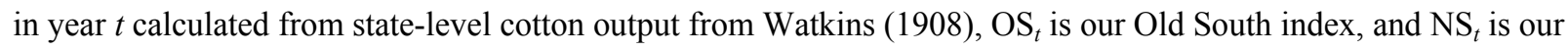
New South index. The weighted index differs from the All South index because our plantation sample contains disproportionately more observations in the New South. We have tried higher-order polynomials in time with essentially the same results.
} 
differences in diffusion rates. The higher picking rates allowed planters to plant more cotton per slave, leading to an increased specialization in cotton production and to an increase in the annual average number of bales harvested per worker.

\section{The Cliometric Mainstream}

The evidence on picking rates offers a far more dynamic picture of southern agricultural development than that depicted in the existing cliometric literature. Attention to southern agricultural productivity has mostly focused on static issues such as the differences in total factor productivity of free farms and slave cotton plantations of various sizes. Changes over time have received short shrift. An abbreviated list of participants in the slavery debates includes Fogel and Engerman (1974) for Time on the Cross, and Fogel and the many other contributors to the four volumes of Without Consent or Contract (Fogel 1989; Fogel and Engerman 1992a, 1992b; Fogel, Galantine, and Manning 1992). Gavin Wright, Peter Temin, Paul David, Roger Ransom, Richard Sutch, William Parker, Robert Gallman, Richard Steckel, Robert Margo, Chris Hanes, Claudia Goldin, Lee Craig, Tom Weiss, Fred Bateman, James Foust, David Weiman, and well over a score of other prominent scholars have made substantive contributions. Parker and Gallman (with their students) played a key role in shaping the contours of the debate by providing their much-cited sample of over 5,000 farms drawn from the 1859 manuscript census.

In The Slavery Debates (2003) Fogel offered his view on the current state of knowledge of slave and plantation efficiency. Notwithstanding all of the fireworks concerning Time on the Cross, Fogel asserted that its major findings remain intact. In particular, he maintained that slave plantations were highly profitable, efficient, and fully capable of out-competing free farms. The greater efficiency of plantations stemmed from their ability to exploit the gang system. Slaves 
"who toiled in the gangs of the intermediate and large plantations were on average over 70 per cent more productive than either free farmers [northern and southern] or slaves on small plantations" (Fogel 2003, pp. 28-39). Finally, Fogel asserted that under the gang system slaves worked more intensely but for fewer hours than free workers. The "greater intensity of labor per hour, rather than more hours of labor per day or more days of labor per year, is the reason the index of total factor productivity is 39 percent higher for the gang-system plantations than for free farms." ${ }^{2}$

Fogel and Engerman's productivity findings remain contested. Wright $(1978,1979$, 2006) and Schaefer (1983) argued the results are unrepresentative because the analysis focused on a single crop year, 1859, which they claimed was exceptionally favorable for cotton. Relying on cross-sectional data also presents difficulties in controlling for unobserved heterogeneity across plantations that cause endogeneity problems. Differences in managerial ability, soil type, or location could have accounted for the correlation between size and measured productivity, and confounded the cross-sectional relationship pointing to the importance of plantation scale.

In response to these critiques, Fogel and Engerman $(1977,1980)$ disputed the claim that 1859 was an exceptionally good year for cotton. ${ }^{3}$ They then posed this question: "What then explains the big increase in the output of cotton between 1850 and 1860?" To answer this question, they employed a simple decomposition model that assumes that the movements in cotton production were largely deduced from state-level changes in improved acreage and corn

\footnotetext{
${ }^{2}$ Fogel argues that small slaveholders (those with 1 to 15 slaves) could not effectively capture the benefits of the gang system, so plantations with more than 15 slaves account for nearly all of the productivity advantage. Large plantations were only slightly more efficient than intermediate size units. See also Toman (2005).

${ }^{3}$ Fogel and Engerman (1977) argue their main findings for 1859 would hold even if cotton productivity were substantially lower in that crop year. Wright (2006) finds significant differences in the production relationships between the 1859 Parker-Gallman sample and the 1849 Foust sample.
} 
production. ${ }^{4}$ Their analysis showed that the westward shift in cotton production explained only about 8 percent of the increase in output between 1850 and 1860 and that the increase in improved land within each state explained 41 percent of the growth in output. They then deduced that 42 percent of the increase in cotton output resulted from a substitution of land within states from other crops to cotton. "These estimates leave a residual of 9 percent to be explained by all other factors including increases in the use of fertilizers, increases in the laborto-land ratio, and random fluctuations in yields" (Fogel and Engerman 1977, p. 282). The subsequent debate on the sources of the increase in cotton output carried on in this tradition by offering various technical refinements but little new data.

The decomposition exercise of Fogel and Engerman may be analyzed using the following equation (where IA is improved acreage):

$\log (\operatorname{Cotton} 1859 / 1849)=\beta_{0}+\beta_{1} \log (\operatorname{IA} 1859 / 1849)+\beta_{2} \log (\operatorname{Corn} 1859 / 1849)$

In the 10-state region of the Cotton South during the $1850 \mathrm{~s}$, cotton production grew at an annualized rate of 7.7 percent, improved acreage grew at a rate of 3.4 percent, and corn production grew at a rate of 1.8 percent. Fogel and Engerman argue, under the maintained hypothesis of constant yields, that cotton output may be expected to grow directly with the growth of improved acreage. This represents the acreage expansion effect that they posit accounts for 41 percent of the increase. They further argue the corn output might be expected grow at the same rate as improved acreage and any difference between those rates was due to a shift toward cotton. This represents the cropland substitution effect that they posit accounts for

\footnotetext{
${ }^{4}$ The approach seems at odds with the finding in Fogel, Galantine, and Manning (1992, p. 200) that "land was not a major constraint on cotton production." Fogel $(1989$, p. 71$)$ notes that just 6 percent of the improved acreage in the Cotton South was planted in the crop and that "the surging demand for cotton during the 1850s put far more pressure on the South's labor supply than on its supply of land."
} 
42 percent of the increase. Thus their argument may be captured with the model's parameters specified as $\beta_{1}=1+\alpha>1$ and $\beta_{2}=-\alpha<0$ :

$\log (\operatorname{Cotton} 1859 / 1849)=\beta_{0}+\log (\operatorname{IA} 1859 / 1849)$

$$
-\alpha[\log (\operatorname{Corn} 1859 / 1849)-\log (\operatorname{IA} 1859 / 1849)]
$$

where $\alpha$ is the ratio of the corn land share to the cotton land share. ${ }^{5}$

In accessing how well Fogel and Engerman's decomposition reflects the realities of southern development, one should ask how tight was the relationship between the growth of cotton production and improved acreage and corn production. It is important to note that improved acreage is a much broader concept than arable or tilled land. Adequate data on the share of improved acreage devoted to specific crops do not become available until the postbellum period. The 1880 census was the first to enumerate crop acreage and yields. The improved-land-to-rural-population ratio was higher in the South in 1880 than in 1850 or 1860, so it is likely that in the antebellum period the share of improved acreage used for crops was lower and that the relationship linking improved land to cotton production was looser. We can calculate the ratio of the sum of acreage in major crops to improved acreage by county in the South in 1880 (excluding the handful of counties where the sum of reported crop acreage exceeded improved land). The land devoted to the 13 major crops-barley, buckwheat, corn, cotton, oats, rye, wheat, hay, tobacco, Irish potatoes, sweet potatoes, rice, and hops-composed 62 percent of improved acreage with a standard deviation of about 21 percent. The coefficient of variation is roughly one-third. Cotton made up 16 percent of acreage with a standard deviation

\footnotetext{
${ }^{5}$ Fogel and Engerman also include an estimate of the effect of western settlement calculated based on combining state-level output shares and data on average antebellum cotton yields from the U.S. Commissioner of Agriculture (1867, p. 415).
} 
of 17 percent. Corn made up 31 percent with a standard deviation of 14 percent. The bottom line is the cotton acreage is not tightly related to improved acreage in this 1880 cross-section.

Turning back to the antebellum period, we can use the more limited census data to examine the relationship between the growth of cotton production and of improved acreage and crop production at the county level. We focus on 423 cotton-producing counties which have consistently defined boundaries over the 1850 to 1860 censuses. ${ }^{6}$ Regressing the growth of the county's cotton output between 1859 and 1849 on the growth of its improved acreage and corn output yields the following results (with the standard errors in the parentheses):

$\log (\operatorname{Cotton} 1859 / 1849)=0.470+0.0447 \log (\mathrm{IA} 1859 / 1849)+1.175 \log (\operatorname{Corn} 1859 / 1849)$

$$
(0.065) \quad(0.124)
$$

$$
N=423, R^{2}=0.371
$$

Thus we find that (1) the relationship of improved acreage with cotton was positive but much less than one-for-one; (2) the relationship of corn production with cotton production was strong and positive, contrary to the negative sign that Fogel and Engerman posited in their crop substitution argument; and (3) the $R^{2}$ is sufficiently low to leave great room for other factors to affect the growth of cotton output. The upshot is that there is little reason to give credence to Fogel and Engerman's widely cited decomposition of the sources of cotton output growth for the 1850s. Placing aside their estimates means that there is significant scope for productivity growth to account for the increase in cotton output over the 1850 s, and more generally over the whole antebellum period.

\footnotetext{
${ }^{6}$ In this sample, the coefficient of variation of the ratio of cotton to improved land is greater than one in both 1850 and 1860 , indicating wide variation in the cross-section.
} 
We want to emphasize that Fogel and Engerman were not alone in overlooking productivity advances. In his earlier work, Wright also downplayed the role of productivity advance in the cotton sector. For example, in Reckoning with Slavery, Wright (1976, pp. 326327) argued "there is very little evidence of substantial productivity growth under slavery other than that associated with the increase in the quantity and quality of cotton land." According to Wright the relocation of cotton production to more fertile soils as well as transportation improvements such as the steamboat and railroad explained the slow secular decline in the real price of cotton. But in Slavery and American Economic Development, Wright (2006, pp. 89-91) acknowledges a greater role for biological learning to increase productivity and encourage the western expansion of the cotton frontier. Other scholars have equated productivity growth with mechanization. As an example, Eugene Genovese (1967, pp. 48-51, 54-61) concluded from the absence of mechanical innovations on par with the grain reaper that the South was stagnating. ${ }^{7}$

\section{The Growth of Cotton Bales per Worker}

A few economic historians have recognized the significance of productivity growth in the cotton sector, but their work hardly caused a ripple in the mainstream literature. Conrad and Meyer (1964, p. 77) compared the growth of cotton output to the adult slave population over the 1800-1860 period and interpreted the wide difference as a sign of productivity advance. But this exercise raised obvious objections. Wright (2006, p. 88) among others has been skeptical of

\footnotetext{
${ }^{7}$ David Weiman (1990, p. 147) also writes of "stagnant agricultural technology" in antebellum southern staples production. Post (2003, p. 296) recounts the bare outlines of the importance of Petit Gulf and of mechanization, but then claims (p. 300): "There is no evidence of systematic and widespread introduction of labour-saving technology in cotton production."
} 
measuring productivity growth in this way, arguing, "This practice is misleading. The composition of southern agricultural output was in flux between 1790 and the 1820 s, as cotton replaced tobacco, wheat, and lesser crops in Virginia and the Carolinas." We agree with Wright's (2006, p. 88) assessment that "it makes little sense to define a productivity measure in terms of only one part of the whole. If that part happens to be rising rapidly, such a ratio exaggerates the growth of what economists normally regard as productivity." Fogel and Engerman (1971, pp. 315-316, esp. fn. 9) expressed similar concerns. In addition to considering the shifting composition of agricultural output, one should account for the fraction of slaves who did not work in cotton as well as for the fraction of cotton produced by free workers.

Relying on more disaggregated data than Conrad and Meyer (1964), Franklee Whartenby (1977, pp. 54, 104-105) estimated that between 1800 and 1840 cotton yields per acre increased by 46 to 78 percent and that the amount of cotton a slave picked a day more than doubled. ${ }^{8}$ For all tasks, Whartenby estimated that the number of bales produced per worker increased 1.9 to 2.3 times over these four decades. The diffusion of new cotton varieties played a leading role in her story. However, given the small size of her sample, Whartenby resisted extending her conclusion to the entire South. Even after Lebergott (1984) added more evidence of productivity gains, cliometricians ignored this path of research. The only other references to biological innovation

\footnotetext{
${ }^{8}$ Many factors might combine to explain her findings, but improved seeds took center stage. Parker (1979, pp. 228244, esp. p. 235) also pondered the possibility of technological changes in southern agriculture but did not pursue this notion. Metzer (1975, pp. 123-150) did examine daily picking rates on the Leak plantation in Tippah, Mississippi, over the 1841-1860 period in order to investigate the treatment of pregnant women. In the spirit of our work on wheat, the calculations of increased output per worker do not fully capture the effects of biological innovations because they do not account for the Red Queen effect. In addition to maintenance problems, Whartenby's estimates do not account for the difficulties growers would have faced pushing out the frontiers of the Cotton Belt without varieties tailored for the new geoclimatic conditions. Olmstead and Rhode (2002; 2008a, pp. 98-154).
} 
in antebellum cotton production that we have found in the economic history literature are Scheiber, Vatter, and Faulkner (1976, p. 131) and Campbell (1988).

Why mainstream cliometricians failed to see the cotton variety revolution is even more puzzling because many of the giants of southern history including James L. Watkins (1908), Louis Cecil Gray (1933), and John Hebron Moore (1956, p. 96; 1958, pp. 13-36; 1988) all touted the essential importance of biological innovation in increasing cotton yields, quality, and picking efficiency. So did many widely read nineteenth-century observers such as Mississippi planter and historian B. C. L. Wailes (1854). Watkins (1908, p. 13) was so impressed with the improved attributes of the Mexican cotton that he proclaimed, "From an economic point of view the introduction of this seed was second in importance to the invention of the saw gin." Cliometricians repeatedly cited these traditional historians and contemporary sources on myriad issues but simply ignored their emphasis on new cotton varieties.

Plantation owners often commented on the number of bales of cotton slaves were expected to produce, could produce, or did produce in a year. As examples, an 1810 advertisement in the Charleston City Gazette claimed the land tract for sale as capable of producing 3 to 4 bales per hand, whereas another ad for land in the 1857 Macon Weekly Telegraph promised 4 to 8 bales. ${ }^{9}$ Historians of the era have followed suit. For instance, John Hebron Moore notes, "Farmers, who in 1800 had hoped to average two 400-pound bales to each field hand, by 1837 were trying to produce crops of six to eight bales to the hand" (Moore, 1958,

\footnotetext{
${ }^{9}$ Charleston, South Carolina, City Gazette and Daily Advertiser. August 27, 1810; "Southwestern Georgia," Macon Weekly Telegraph, January 27, 1857. Among the prominent antebellum estimates of bales-per-hand ratios are Woodbury (1836, p. 14) and DeBow (1854, vol. 1, p. 175). The emphasis on bales per worker as opposed to bales per acre is fairly common and in line with Wright's depiction of planters as first and foremost "labor lords." There exists a problem in comparing bale-per-worker quotes over time; bale weights generally increased over the antebellum period. Watkins (1895) reports their net weight averaged about 225 pounds in 1800, 339 in 1830, and 461 in 1860.
} 
p. 46). Moore further observed that "in the years 1833 and 1836 Richard Nutt, son of Dr. Rush Nutt, averaged nine bales of cotton to the hand, a record almost equaled by his brother" (Moore 1958, p. 215, fn. 26).

Although there are many similar claims ascribing 5 to 10 bales per slave, Foust and Swan (1970) suggest that such anecdotal accounts painted an excessively rosy picture of average conditions. Foust and Swan examined the labor-input and cotton-output data in 1849 and 1859 for a sample of farms in 74 cotton-producing counties. Both the 1849 and 1859 samples contained well over 500 cotton farms. They did not rely on direct individual observations of picking rates as we do above, but rather they calculated the output per slave using farm-level cotton output in bales divided by one-half of the number of slaves on a given plantation to arrive at a rough approximation of the number of full field hands (also see Sutch 1965). This represents a vast improvement over Conrad and Meyer's procedure of comparing U.S. cotton production to the entire slave population aged 10 to 54 years old. Foust and Swan found that bales per working slave increased from 1.59 in 1849 to 2.11 in 1859 . On "Alluvial" lands the increase was from 2.07 to 2.78, for their "Other New South" region bales per slave went from 1.49 to 2.64, and for their "Old South" region it only went from 1.47 to 1.48 . One might question how sensitive these results are to the underlying assumptions and to the weather and other conditions in the two years studied, but there is no denying that something very important was going on. For the South as a whole, the bales per worker went up by an average of 2.8 percent per year; for the "Alluvial" lands and the "Other New South," the increases were 2.9 percent and 5.7 percent per year respectively. By contrast there was no change the "Old South."10

\footnotetext{
${ }^{10}$ Fogel and Engerman (1971, pp. 315-316) argue the soaring cotton output per worker between 1850 and 1860 "strongly suggests that other inputs required for cotton production increased more rapidly than labor."
} 
The Foust and Swan 1859 ratios are means derived from the Parker-Gallman sample. It is informative to explore in greater detail the distributions of the ratio of bales per slave worker in this benchmark sample. We will focus on cotton operations with one or more slaves (age 10 years and over). Such operations account for 91.1 percent of cotton in the overall sample, 92.0 percent in the Old South, and 90.8 percent in the New South. The top panel of Figure 2 graphs the cumulative distribution of farms and plantations by bales per slave. In the Old South, 51 percent of units in the sample had a bale-to-slave ratio of two or less, whereas in the New South 23 percent did. More than 86 percent of the Old South units had a bale-to-slave ratio of five or less, while only 69 percent of New South units did. By this measure the median ratio was 2 bales in the Old South and 3.69 in the New South. The middle and bottom panels graph the cumulative distributions of slaves and cotton production, respectively. The median ratio of bales per working slave was 1.86 in the Old South and 3.67 in the New South, almost twice as high. By each measure the bales-to-slave ratio was substantially higher in the New South than in the Old South.

Employing a data set recently constructed by Craig and Weiss (1998), we can push estimates of bales-per-hand back to 1800 . Craig and Weiss created separate estimates of the urban and rural labor force by county in the United States and then for the South assumed about 75 percent of the rural slaves worked in agriculture. This ratio was based on detailed statistics drawn from the 1840 census and is consistent with the finding that a substantial fraction of rural slaves worked in domestic or craft trades. ${ }^{11}$ They report numbers of male and female agricultural

\footnotetext{
${ }^{11}$ Weiss (1987) and Craig and Weiss (1998) created state and county estimates of the number of agricultural slaves in the labor force, whereas Lebergott (1966) and David (1967) worked only with national figures. Lebergott and David assumed that 95 percent of slaves (age 10 years and over) lived in rural areas and that 87 to 90 percent of these slaves worked in agriculture. As a check against the conventional approach, the Craig-Weiss numbers imply for 1860 that 48.5 percent of all slaves in the ten-state Cotton South worked in agriculture.
} 
slaves (age 10 and over) and free workers (10 to 15 and 16 and over). We summed their estimates of the agricultural labor force over the cotton counties in each state and region. For 1800-1830 the cotton counties are those designated on the USDA maps. For 1840-1860 the cotton counties are those with production equal to or greater than 1,000 bales. In 1859 the designated cotton counties accounted for 98.6 percent of the total crop, in 184997.3 percent, and in 183997.3 percent. Thus almost all cotton production is covered. In addition, most tobacco, hemp, rice, and sugar cane production is excluded.

Table 1 shows two estimates of the ratio of cotton bales produced to the number of agricultural workers from 1800 to 1860 . The top panel shows the bales per slave worker and the bottom panel includes both slave and free workers. ${ }^{12}$ Figure 8.3 provides a visual representation of the same data. ${ }^{13}$ According to the top panel in Table 8.1, the national ratio of cotton bales to agricultural slave workers rose over 4.1 times between 1800 and 1860 . This represented a 2.4 percent increase per annum. The ratio grew in both the Old South and New South. The rise in bales per worker in the Old South calls into question interpretations stressing declining soils and

\footnotetext{
${ }^{12}$ We constructed the regional cotton production data by multiplying total cotton output found in the Historical Statistics of the United States by three-year-moving averages of state production shares drawn from Watkins (1908, passim). Our methodology assumes that, for each year, Watkins reported bales of the same weight for each state (Fogel et al. 1992, p. 193 implicitly treats the Watkins data in the same way). If bale weights are not standardized over space and if bales from the Gulf ports were initially heavier than those of the Atlantic ports and if the weights converged (as data from the Liverpool trade suggest), then the actual interregional cotton-pounds-per-worker gaps in the early period would have been even greater than our series indicates. In addition, the actual growth of total output and output per worker in the Old South would be greater than what is indicated.

${ }^{13}$ The bales-per-worker statistics reported here are based on more highly aggregated data than those of Foust and Swan (1970). Nonetheless, in the comparison of similar regions, the correlation coefficient between the Foust and Swan numbers and our census bales-per-slave ratios is 0.66 over the combined 1850 and 1860 samples. Comparing our national aggregate numbers with those presented by Whartenby (1977, p. 54) for 1800 to 1840 reveals her numbers start higher in 1800 but reach roughly the same range as ours by 1840 .
} 
falling productivity in the Southeast. ${ }^{14}$ Though often depicted as a backwater in antebellum development, the Old South experienced annual growth rates of 4.2 percent in cotton production and 1.6 percent in bales per worker. Cotton production in the New South, of course, expanded even more rapidly because of the availability of new land and higher productivity. The ratio of cotton bales to agricultural slaves in the New South was 89 percent higher than in the Old South in 1810 and 109 percent higher in 1860 . Herein was a great incentive to send slaves west. The rapid growth in the bales per worker for the entire South reflects the significant shift in the composition of output from the Old to the New South. In 1810 the Old South produced 95 percent of America's upland cotton; by 1860 this region only produced less than 24 percent. A standard decomposition calculation using data for these two regions over the 1800 to 1860 period reveals about one-half of the increase in the national bales-per-slave ratio was caused by the shift between the two regions and the other half by increases within each region.

A similar picture appears in the bottom panels of Table 1 and Figure 3. The ratios are obviously lower (because the denominator is larger), but the growth rates are somewhat more rapid because the free labor force grew more slowly than the slave labor force in the cotton areas. It is not obvious which labor force estimate is most appropriate. Indeed, we suggest that for the early years the bottom panel (with slave and free labor) deserves more attention, and for the later years the top panel (with only slave labor) should gain the spotlight. Early in the nineteenth century free whites played a larger role in cotton production. Mendenhall (1940) asserted that cotton was initially (in the 1790s) a small farmer's crop in the Southeast and was only gradually

\footnotetext{
${ }^{14}$ This result supports Fogel's (1989, p. 71) conclusion: “Analysis of census data reveals no evidence of the decline in labor productivity on farms of the Old South that would have been caused by a decline in the quantity or quality of land per worker." Part of the increase in bales per worker in the Old South may have been caused by movement to better lands in western Georgia and elsewhere within the region.
} 
adopted by the larger slaveholders. Based on Hammond and other antebellum observers, Whartenby (1977, pp. 67-70) placed the number of free whites producing cotton in the 18001830 period at one-sixth the number of slaves engaged. By the 1850 s cotton was overwhelmingly a slave crop. Foust's research indicates that free white farms account for only 5 to 10 percent of the crop - a share that is only slightly above what Campbell $(1988, \mathrm{p} .167)$ estimated enslaved African Americans produced on their own time for sale to their masters. If the composition of the cotton labor force in fact shifted dramatically away from free workers, the ratio of bales to cotton worker rose more rapidly than either panel alone suggests.

Figure 4 provides a visual sense of the variation across space and changes over time based on county-level data for 1840,1850 , and 1860 . The panels map the number of the 400 pound bales produced per slave worker and per worker, slave and free, constructed from the census output data and Craig-Weiss labor force estimates. The dramatically higher levels of production per worker in specific areas of the Southwest jump out.

Both our aggregate and county-level census data on bales per cotton worker are consistent with Foust and Swan's findings that bales per hand remained stagnant in the Old South during the 1850s. Lacking the longer view provided here, Foust and Swan were not able to see this decade as an exception to otherwise vibrant growth in the Old South. The census data are also consistent with Wright's claim that the South's rapid growth in income between 1850 and 1860 was due, in part, to crop-year effects in 1849 and 1859. Surveying the county-level data shows that large areas of the South, and in particular a swath of prime land along the lower Mississippi, recorded fewer bales per worker in 1849 than in either 1839 or 1859 . The Old South did not suffer noticeable declines in 1849 relative to the other two years. This relatively 
favorable 1849 base likely accounts for the Old South's relatively poor showing during the $1850 \mathrm{~s}$.

The next step is to obtain a more detailed sense of the importance of the changes in bales per worker shown in Table 2 and Figure 4 relative to other factors, including the regional shifts in the labor force. To do this we conduct a decomposition exercise for total cotton output and average bales per worker using county-level data for 1840 to1860. The results are presented in Table 2. ${ }^{15}$ It asks what would happen to total output (panel A) and average bales per worker (panel B) if the labor force in the initial year achieved the bales per worker prevailing in a latter year.

Panel A in Table 2 examines changes in total output, combining the effects of growth of the slave labor force, shifts in its regional allocation, and changes in bales per worker. It varies the slave labor force by county along the rows and the bales per worker by county across the columns. As an example, the entry " 1,969 " represents the sum of 1840 county bales per worker weighted by the 1840 county slave labor force numbers; it is a factual level of production. By way of contrast, " 1,733 ” represents the sum of 1850 county bales per worker weighted by the 1840 county slave force numbers; it is the counterfactual estimate of production assuming that the 1840 distribution of laborers somehow attained the 1850 levels of bales per worker.

Total output increased from $1,969,000$ bales in 1840 to $5,360,000$ in 1860 , or by 5.0 percent per annum. Over this period the aggregate slave labor force working in agriculture in

\footnotetext{
${ }^{15}$ Our analysis concentrates on those counties producing 1,000 bales or more. The exercise accounts for changes in county borders over time by forming separate panels for 1840, 1850, and 1860 of consistently defined counties and summing the production and labor force numbers within these entities over the sample years. These panels are unbalanced because the process of western settlement created numerous new counties over time. The absence of cotton-bales-per-worker data until a county was settled and began to produce cotton necessitates conducting the analysis forward, not backward. That is, it is not meaningful to consider the cells in Table 2 below the diagonal.
} 
these counties increased 2.1 percent per annum, whereas the average bales per worker increased by 79 percent, or 2.9 percent per annum. Table 2 indicates that if the only change that happened was that the 1840 labor force in each county attained its 1860 levels of bales per worker, total production would have summed to just 2,683,000 bales. Growth would have been only 21 percent of what actually occurred between 1840 and 1860. To offer a different perspective, we perform a new calculation showing that if the cotton labor force grew from 960,000 slaves in 1840 to $1,460,000$ (the 1860 number) but bales per worker remained at the 1840 level of 2.05, the total counterfactual level of cotton output would have risen by 1,025,000 bales. Thus the change in the size of the labor force holding bales per worker constant accounted for 30 percent of the increase in output that actually occurred between 1840 and 1860 . Adding this to the 21 percent attributed to the changes in county-level bales per worker suggests that regional shifts together with interaction effects account for the remaining 49 percent of the change in output. ${ }^{16}$ This is a far different story than that found in the cliometrics literature.

Panel B examines changes in average bales per worker. This is more relevant for an analysis of productivity, although of course the bales-per-worker measure embraces both specialization in cotton and efficiency in its production. Average bales per worker grew substantially between 1840 and 1860, with most of the change occurring in the 1850-1860 period. Over the 1840-1860 period, within-county changes in cotton per worker account for 46 percent of the total increase (that is, $[2.79-2.05] /[3.67-2.05])$. Over the 1850 to 1860 period, within-county changes account for 80 percent of the total change. In each comparison, the remainder may be interpreted as the effect of regional shifts (together with any interaction

\footnotetext{
${ }^{16}$ Note that this (and all other) decomposition exercise mechanically shifts some values while holding constant others, which may not reflect their true underlying relationships. For example, average output per worker in a county might fall as the local labor force increased.
} 
terms). ${ }^{17}$ The summary view from this decomposition exercise is that, over the whole 1840 to 1860 period, within-county changes and regional shifts made roughly equal contributions to the large increase in average bales per worker. This result on the importance of regional shifts in explaining the increase in bales per worker in the Cotton South is many times larger than Easterlin (1975) and Weiss (1987) found for total agricultural output per worker nationally over the same period. For example, Weiss (1987, pp. 18-19) attributed about 10 percent of the increase in agricultural output per worker to shifts in the regional composition of the labor force.

One must be cautious in interpreting these results because the data clearly indicate that there were crop year effects. Although estimate of the actual bales per worker in 1850 was higher than in 1840, the counterfactual number (holding the 1840 labor force distribution constant) is about 12 percent below the actual 1840 number. Such crop year effects highlight an important advantage of using archival plantation records spanning many years (Olmstead and Rhode 2008a, Olmstead and Rhode 2008b). As another caveat, the analysis starts in 1840, and as we have seen above there are signs that productivity rose more rapidly in earlier decades. ${ }^{18} \mathrm{It}$ is notable that the patterns over time and across regions for the bales-per-worker series displayed in Table 8.1 are in remarkably close accord with independent evidence on daily cotton picking rates from our sample drawn from archival plantation documents discussed above. Our findings of sustained increases in picking efficiency and of substantial regional differences in the growth of picking efficiency lead to a new view of the broader contours of southern development such as the territorial expansion of the cotton-slave frontier.

\footnotetext{
${ }^{17}$ There is some evidence of an interaction effect (specifically of greater changes in cotton per worker in the new areas with increasing labor force shares) in the more rapid growth between 1850 and 1860 using the 1850 weights than using the 1840 weights.

${ }^{18}$ The lower estimate of the relative importance of regional shifts in the 1850s suggests that literature's focus on the 1850 s has generated conclusions not representative of longer-run development patterns.
} 


\section{Territorial Expansion}

In the early 1790s production of cotton was concentrated along the coast of Georgia and South Carolina. By 1839 the geographic center of the production of upland cotton was near Greensboro in west-central Alabama, and by 1859 it was across the Mississippi-Alabama border. The speed of westward expansion of cotton production in the antebellum period is all the more impressive when one realizes that over the next 60 years, the geographic center of production remained within the boundaries of the state of Mississippi. Annual series of commercial cotton output in Watkins (1908) show the movement away from the Atlantic Seaboard states (Virginia, North Carolina, South Carolina, Georgia, and Florida) began in earnest in the early 1810 s. Their share of production fell from over 95 percent in 1810 to less than one-half by 1833 and to less than one-quarter by 1859 .

There have been numerous claims and counterclaims about the effects of westward expansion on southern political and economic fortunes. In his classic Slave Power, Cairnes (1862) argued the slave system needed to expand to new lands to retain viability because slave production of cotton exhausted the fertility of existing soils. Ramsdell (1929) countered that the natural environmental limits to the system were being reached by the late 1850 s, and continued expansion (for example, with the railroad allowing the spread into Texas) would herald slavery's doom by leading to "over production" and lower cotton and slave prices. Gray (1930, p. 46) asserted that the availability of new highly productive lands on the frontier increased slave prices, which in turn drove down land prices in the older area. In addition, it made production in the older areas "unprofitable" but only in the relative sense that the opportunity costs of producing outside the Southwest were so high. According to Gray, the differentials in regional 
productivity and profitability led observers to mistakenly conclude "that slavery can thrive only on the basis of geographical expansion and a migratory economy, that slavery is adapted only to extensive agriculture, that it inevitably results in soil exhaustion, and that it cannot be profitable in general farming." Genovese (1967, p. 247) posited that outmigration to the Southwest had a negative impact on productivity in the Southeast by retarding much-needed agricultural reforms and drawing away workers who could have been employed rebuilding depleted fields. Even Conrad and Meyer (1958, p. 115) were concerned with regional interactions, arguing that the success of the Old South was due to its "function as the slave-breeding area for the cotton-raising West." Throughout many traditional accounts, the expansion of slavery is intertwined with claims about profitability and viability and with broader strategic issues such as the maintenance of the South's power in the U.S. Senate.

In the 1960s and 1970s most economic historians concluded that slavery was both profitable and viable, but many issues dealing with western settlement remained unresolved. There were three major lines of inquiry. The first debated how to interpret the estimates of regional per capita income growth displayed in Table 3. These statistics, developed by Easterlin (1961) and refined by Engerman (1967, pp. 85-87, 94-95), show the South as a whole grew faster than the national average between 1840 and 1860, but each of the South's three subregions grew as a slower pace. The high overall performance was due to a reallocation of population from the low-income Southeast to the higher-income Southwest, leading to the interpretation that the region's growth hinged crucially on territorial expansion as opposed to internal development. Antebellum southern growth, in the view of many scholars, was largely based on the exploitation of a natural resource that once settled could not be a source of future growth (Parker, 1970, p. 119; Wright, 1976, p. 324; Weiman, 1990, pp. 128, 131, and 147-148). By contrast, in the North 
the transfer of resources from the agricultural to the nonagricultural sectors rested on the growing productivity in the later sector. This view clearly needs to be refined. We do not dispute that there was relatively little industrialization in the South or that southerners were moving resources to more productive lands in the West. But technological changes were also at work in the South; specifically, biological innovations significantly increased cotton productivity, especially in the West. These rapid advances acted to keep southern resources in agriculture and thus did not create a more diversified economic base as occurred in the North.

The second line of inquiry examined how the institution of slavery conditioned regional migration. Researchers estimated the interregional flows of the free and slave populations, focusing on ascertaining the fraction of slaves that went west with slave traders versus with their masters (Fogel and Engerman 1974, vol. 1, p. 48; McClelland and Zeckhauser 1983; Tadman 1989, p. 45; Pritchett 2001). A related literature has explored how property rights in slaves sped the expansion of slavery to the more productive Southwest. Attachment to family and place received far lower weight for a slave than for a free person in the migration calculus. In addition, the ability of large planters to capitalize (and borrow against) the enhanced value of their slaves' labor helped to finance migration and the purchase of large tracts of the most fertile western lands (Wright 1986, pp. 24-26; Wright 2006, pp. 66-70; Weiman 1990, pp. 135-140; Weiman, 1991 pp. 836-837). Our picking data provides addition insight. They show that productivity of females in this key task was very close to that of males. High picking potentials in the New South created incentives to move both females and males west and help account for the more balanced gender ratios in the Southwest in comparison with the Northwest.

The third line of inquiry used general equilibrium models to analyze the impacts of adding land endowments on the prices of cotton and slaves, on the allocation of labor, and on the 
financial welfare of different southern interest groups. These exercises reached two novel conclusions that arose from (1) the South's position as the dominant supplier of a product with imperfectly elastic demand and (2) the role of the Old South as a seller of slaves to the New South. Given the assumption of an inelastic demand for southern cotton, Passell (1971) noted that westward expansion likely reduced southern income. Passell and Wright (1972) concluded that for each 10 percent addition of land, the value of the marginal product of slaves would fall by 1.2 to 1.8 percent and the average price of slaves by 1.3 to 1.9 percent. Lee $(1977,1978)$ found that the effect on the price of land in existing cotton areas was even greater. Based on their two-region general equilibrium model, Kotlikoff and Pinera (1977) similarly argued that producers in the Old South had good reason to fear adverse effects from westward expansion. If the elasticity of demand for the South's agricultural output were infinite, a doubling of land in the Southwest would have increased wealth in the Southeast by about 2 percent. Were the elasticity minus unity (meaning that the output price would have moved inversely in exact proportion to the level of southern output), a doubling of land in the Southwest would have decreased wealth in the Southeast by about 20 percent. These results supported the intuitions of Ramsdell rather than those of Cairnes. ${ }^{19}$ This line of investigation has generally viewed westward expansion as a process of static reallocation of labor to inherently better soils rather

\footnotetext{
${ }^{19}$ For a counterview, see Schmitz and Schaefer (1981). The cliometrics literature has the relationship between territorial expansion and market power backward in important cases such as the annexation of Texas. The pursuit of continued dominance in the cotton trade stimulated rather than deterred expansion. Advocates for annexation argued adding Texas was necessary to maintain the country's "cotton monopoly," especially in the face of British efforts to develop alternative sources of supply, including those relying on free labor. Cotton production in Texas was likely to expand rapidly after 1840 regardless of whether it joined the United States. Controlling the world's "most favored" cotton lands enhanced the South's commercial and strategic positions in line with what was later known as "King Cotton thinking." See Walker (1844, pp. 15-17) and Crapol (2006, pp. 65-69).
} 
than as a response to the increasing comparative advantage of the New South due to technological progress.

However, acknowledging the technological changes underway in the South casts a new light on this general equilibrium debate. The first important cotton variety innovations came from western plantations, and throughout the antebellum period southeastern planters relied on the Southwest for most breeding improvements. As history transpired, the South's ability to produce high-quality and easy-to-pick cotton was a key ingredient allowing the United States to capture international markets. The technological advances underlying this process depended on westward movement at least up to roughly 1850 . Without the new southern cotton varieties, India and other areas would have produced closer substitutes and competed more effectively, thereby slowing the growth in demand for the U.S. product. This would have made the demand for U.S. cotton far more elastic and changed the general equilibrium calculations. Southeastern planters would have faced more price competition from foreigners and would have seen the value of their slaves fall without the compensating growth in the western demand for their chattel. The new seeds also created an additional channel, beyond the expansion of cultivated acreage facilitated by public land sales, to increase cotton output in the South. Thus allowing for biological innovation dramatically affects the general equilibrium story.

\section{Conclusion}

The antebellum southern development literature has long maintained that cotton producers in the New South enjoyed a productivity advantage because they had inherently better land than producers in the Old South. Moreover, the virgin land in the West had not yet been 
mined of its nutrients. The long-standing explanations of east-west productivity differences are seriously deficient. The rapid shift in production in the years before 1840 occurred precisely when New South cotton producers enjoyed a significant varietal advantage over Old South producers. This is evident in two independent time series - data on daily picking per slave and data on annual bales produced per worker. The new biological technologies represented an improvement on a wide spectrum of soil types, but the new seeds were particularly suited to the fertile lands and climates where they originated. The large plantation regions of the New South had better soils to start with, but in a sense a stream of biological innovations made these soils increasingly better, both absolutely and relatively. Western movement did not just involve adding more acres of higher-quality land as assumed in the general equilibrium debate; the western shift was associated with moving to higher and higher production possibility frontiers.

It is well understood that in recent decades scientists have made spectacular advances in breeding higher-yielding plants, which laid the foundations of the green and genetic revolutions. But it is not common to think of early nineteenth-century farmers and scientists molding and remolding their plants to enhance performance. The cliometricians who pondered the data showing an increase in cotton bales per hand drew all sorts of inferences: this was evidence of an increase in non-labor inputs, of the improved management skills of plantation owners and drivers (especially in utilizing the gang system), of the transfer of production to better land, of differential weather between two data points, or of a change in the composition of output and a resulting miscalculation of the true size of the workforce in cotton. The recent cliometrics debate never seriously considered whether technological change and improved productivity, the stuff of modern economic growth, led to increased output per worker in the Cotton South. Yet, this is precisely what happened. The development of improved seeds represented a form of endogenous 
technological change in response to emerging economic opportunities in the region. The spatial pattern of the productivity advances help explain why regional shifts in the location of production were far more important than previously thought in explaining the overall growth in southern cotton production, the increase in cotton per worker, and the dynamics of plantation efficiency. Finally, allowing for technological change cast an entirely new light on the general equilibrium literature, suggesting that western movement was less adverse to southeastern interests as previous estimates suggest. 


\section{References}

Anderson, Ralph V. (1974). "Labor Utilization and Productivity, Diversification and SelfSufficiency, Southern Plantations, 1800-1840.” PhD diss., University of North Carolina.

Anderson, Ralph V., and Robert E. Gallman (1977). "Slaves as Fixed Capital: Slave Labor and Southern Economic Development." Journal of American History 64: 24-46.

Cairnes, John E. (1862). Slave Power: Its Character, Career And Probable Designs, Being an Attempt to explain the American Contest. London: J. Chapman.

Campbell, John Douglas (1988). "The Gender Division of Labor, Slave Reproduction, and the Slave Family Economy on Southern Cotton Plantations, 1800-1864.” PhD diss., University of Minnesota.

Carter, Susan B., Scott Sigmund Gartner, Michael R. Haines, Alan L. Olmstead, Richard Sutch, and Gavin Wright, eds. (2006). Historical Statistics of the United States, Earliest Times to the Present: Millennial Edition. New York: Cambridge University Press.

Conrad, Alfred H., and John R. Meyer (1958). "The Economics of Slavery in the Ante-Bellum South.” Journal of Political Economy 66: 95-122.

Conrad, Alfred H., and John R. Meyer (1964). The Economics of Slavery and Other Studies in Econometric History. Chicago: Aldine.

Craig, Lee A., and Thomas Weiss (1998). "Rural Agricultural Workforce by County, 1800 to 1900” [Computer file]. Downloaded from http://eh.net/databases/agriculture/

Craig, Lee A., Michael R. Haines, and Thomas Weiss (2000). “U.S. Censuses of Agriculture, by County, 1840-1880" [Computer file]. Raleigh: Unpublished files provided by the authors, Department of Economics, North Carolina State University. 
Crapol, Edward P. (2006). John Tyler, the Accidental President. Chapel Hill: University of North Carolina Press.

David, Paul (1967). "The Growth of Real Product in the United States Before 1840: New Evidence, Controlled Conjectures." Journal of Economic History 27: 151-97.

DeBow, J. D. B. (1854). “Cotton and Its Prospects.” In Industrial Resources, Statistics, etc. of the United States. Vol. 1. New York: Appleton, pp. 174-178.

Easterlin, Richard A. (1961). "Regional Income Trends, 1840-1950.” In American Economic History, edited by Seymour Harris. New York: McGraw-Hill, pp. 525-547.

Easterlin, Richard A. (1975). "Farm Production and Income in Old and New Areas at MidCentury." In Essays in Nineteenth Century Economic History: The Old Northwest, edited by David C. Klingaman and Richard K. Vedder. Athens: Ohio University Press, pp. 77117.

Eltis, David, Frank D. Lewis, and Kenneth L. Sokoloff (2004). Slavery in the Development of the Americas. New York: Cambridge University Press.

Engerman, Stanley L. (1967). "The Effects of Slavery upon the Southern Economy: A Review of the Recent Debate." Explorations in Entrepreneurial History 4: 71-97.

Engerman, Stanley L. (2000). "Slavery and Its Consequences for the South in the Nineteenth Century." In Cambridge Economic History of the United States, edited by Stanley Engerman and Robert E. Gallman. Cambridge: Cambridge University Press, pp. 329366.

Engerman, Stanley L. (2007). Slavery, Emancipation, and Freedom: Comparative Perspectives. Baton Rouge: Louisiana State University Press. 
Fogel, Robert W. (1989). Without Consent or Contract: The Rise and Fall of American Slavery. New York: Norton.

Fogel, Robert W. (2003). The Slavery Debates, 1952-1990: A Memoir. Baton Rouge: Louisiana State University Press.

Fogel, Robert W., and Stanley L. Engerman (1971). “The Economics of Slavery.” In ReInterpretation of American Economic History, edited by Robert W. Fogel and Stanley L. Engerman. New York: Harper and Row, pp. 331-341.

Fogel, Robert W., and Stanley L. Engerman (1974). Time on the Cross: The Economics of American Negro Slavery. 2 vols. Boston: Little, Brown.

Fogel, Robert W., and Stanley L. Engerman (1977). "Explaining the Relative Efficiency of Slave Agriculture in the Antebellum South." American Economic Review 67: 275-296.

Fogel, Robert W., and Stanley L. Engerman (1980). “Explaining the Relative Efficiency of Slave Agriculture in the Antebellum South: Reply." American Economic Review 70: 672-690.

Fogel, Robert W., and Stanley L. Engerman, eds. (1992a). Without Consent or Contract: The Rise and Fall of American Slavery, vol. 3: Technical Papers, vol. 1:, Markets and Production. New York: Norton.

Fogel, Robert W., and Stanley L. Engerman, eds. (1992b). Without Consent or Contract: The Rise and Fall of American Slavery, vol. 4: Technical Papers, vol. 2: Conditions of Slave Life and the Transition to Freedom. New York: Norton.

Fogel, Robert W., Ralph A. Galantine, and Richard L. Manning, eds. (1992). Without Consent or Contract: The Rise and Fall of American Slavery, vol. 2: Evidence and Methods. New York: Norton. 
Foust, James D. (1967). “The Yeoman Farmer and Westward Expansion of U.S. Cotton Production." Journal of Economic History 27: 611-614.

Foust, James D. (1975). The Yeoman Farmer and Westward Expansion of U. S. Cotton Production. New York: Arno Press.

Foust, James D., and Dale E. Swan (1970). "Productivity and Profitability of Antebellum Slave Labor: A Micro-Approach.” Agricultural History 44: 39-62.

Gallman, Robert E. (1970). "Self-Sufficiency in the Cotton Economy of the Antebellum South." Agricultural History 46: 5-24.

Genovese, Eugene D. (1967). The Political Economy of Slavery: Studies in the Economy and Society of the Slave South. New York: Vintage.

Gray, Lewis C. (1930). "Economic Efficiency and Competitive Advantages of Slavery under the Plantation System." Agricultural History 4: 31-47.

Gray, Lewis C. (1933). History of Agriculture in the Southern United States to 1860, vol. 2. Washington, DC: Carnegie Institution.

Hietala, Thomas R. (1985). Manifest Design: Anxious Aggrandizement in Late Jacksonian America. Ithaca, NY: Cornell University Press.

Kotlikoff, Laurence and Sebastian Pinera (1977). “The Old South's Stake in the Interregional Movement of Slaves, 1850-1860.” Journal of Economic History 37: 434-450.

Lebergott, Stanley (1966). "Labor Force and Employment, 1800-1960," in Output, Employment, and Productivity in the United States after 1800, Studies in Income and Wealth, Vol. 30, edited by Dorothy S. Brady, New York: Columbia Univ. Press, pp. 117-204.

Lebergott, Stanley (1984). The Americans: An Economic Record. New York: Norton. 
Lee, Susan P. (1977). The Westward Movement of the Cotton Economy, 1840-1860: Perceived Interests and Economic Reality. New York: Arno Press.

Lee, Susan P. (1978). “Antebellum Land Expansion: Another View.” Agricultural History 52: 488-502.

Lewis, Frank, and Kenneth Sokoloff, eds. (2005). Factor Endowments, Labor and Economic Growth in the Americas. Cambridge: Cambridge University Press.

McClelland, Peter D., and Richard Zeckhauser (1983). Demographic Dimensions of the New Republic: American Interregional Migration, Vital Statistics, and Manumissions, 18001860. New York: Cambridge University Press.

Mendenhall, Marjorie S. (1940). "A History of Agriculture in South Carolina, 1790 to 1860.” PhD diss., University of North Carolina at Chapel Hill.

Metzer, Jacob (1975). "Rational Management, Modern Business Practices, and Economies of Scale in Antebellum Southern Plantation.” Explorations in Economic History 12: 123150.

Moore, John Hebron (1956). "Cotton Breeding in the Old South.” Agricultural History 30: 95104.

Moore, John Hebron (1958). Agriculture in Ante-Bellum Mississippi. New York: Bookman Associates.

Moore, John Hebron (1988). The Emergence of the Cotton Kingdom in the Old Southwest, Mississippi, 1770-1860. Baton Rouge: Louisiana State University Press.

Olmstead, Alan L., and Paul W. Rhode (2002). "The Red Queen and the Hard Reds." Journal of Economic History 62: 929-966. 
Olmstead, Alan L., and Paul W. Rhode (2008a). Creating Abundance: Biological Innovation and American Agricultural Development. New York: Cambridge University Press.

Olmstead, Alan L., and Paul W. Rhode (2008b). "Biological Innovation and Productivity Growth in the Antebellum Cotton Economy." Journal of Economic History 68: 1123-1171.

Parker, William N. (1970). "Slavery and Southern Economic Development: An Hypothesis and Some Evidence." In The Structure of the Cotton Economy of the Antebellum South, edited by William N. Parker. Washington, DC: Agricultural History Society, pp. 115-126.

Parker, William N., ed. (1970). The Structure of the Cotton Economy of the Antebellum South. Washington, DC: Agricultural History Society.

Parker, William N. (1979). "Labor Productivity in Cotton Farming: The History of a Research." Agricultural History 53: 228-244.

Parker, William N., and Robert E. Gallman (1991). "Southern Farms Study, 1860" [Computer file]. ICPSR07419-v1. Ann Arbor, MI: Inter-university Consortium for Political and Social Research [distributor]. doi:10.3886/ICPSR07419.

Passell, Peter (1971). "The Impact of Cotton Land Distribution on the Antebellum Economy." Journal of Economic History 31:917-937

Passell, Peter, and Gavin Wright (1972). "The Effects of Pre-Civil War Territorial Expansion on the Price of Slaves." Journal of Political Economy 80: 1188-1202.

Post, Charles (2003). "Plantation Slavery and Economic Development in the Antebellum Southern United States." Journal of Agrarian Change 3: 289-332.

Pritchett, Jonathan B. (2001). "Quantitative Estimates of the United States Interregional Slave Trade, 1820-1860." Journal of Economic History 61: 467-475. 
Ramsdell, Charles W. (1929). “The Natural Limits of Slavery Expansion.” Mississippi Valley Historical Review 16: 151-171.

Schaefer, Donald (1983). "The Effect of the 1859 Crop Year upon Relative Productivity in the Antebellum Cotton South.” Journal of Economic History 43: 851-865.

Scheiber, Harry N., Harold G. Vatter, and Harold U. Faulkner (1976). American Economic History. New York: Harper and Row.

Schmitz, Mark, and Donald Schaefer (1981). "Paradox Lost: Westward Expansion and Slave Prices before the Civil War." Journal of Economic History 41: 402-407.

Sutch, Richard (1965). "The Profitability of Ante Bellum Slavery—Revisited.” Southern Economic Journal 31: 365-383.

Tadman, Michael (1989). Speculators and Slaves: Masters, Traders, and Slaves in the Old South. Madison: University of Wisconsin Press.

Toman, J. T. (2005). “The Gang System and Comparative Advantage." Explorations in Economic History 42: 310-323.

U.S. Commissioner of Agriculture (1867). 1867 Annual Report. Washington, DC: Government Printing Office.

Wailes, B. C. L. (1854). Report of the Agriculture and Geology of Mississippi Embracing a Sketch of the Social and Natural History of the State. Jackson, MS: E. Barksdale.

Walker, Robert J. (1844). Letter of Mr. Walker of Mississippi, Relative to the Reannexation of Texas. Philadelphia: Mifflin and Perry, available at http://www.tsl.state.tx.us/exhibits/annexation/part4/walker_letter_1844_14-15.html. 
Ware, Jacob Osborn (1950). "Origin, Rise and Development of American Upland Cotton Varieties and Their Status at Present." Mimeo, University of Arkansas College of Agriculture, Agricultural Experiment Station.

Watkins, James L. (1895). Production and Price of Cotton for One Hundred Years. U.S. Department of Agriculture Division of Statistics Miscellaneous Series Bulletin No. 9. Washington, DC: Government Printing Office.

Watkins, James L. (1908). King Cotton. New York: Negro Universities Press, reprinted in 1969. Weiman, David E. (1990). "Staple Crops and Slave Plantations: Alternative Perspectives on Regional Development in the Antebellum Cotton South.” In Agriculture and National Development: Views on the Nineteenth Century, edited by Lou Ferleger. Ames: Iowa State University Press, pp. 119-161.

Weiman, David E. (1991). "Peopling the Land by Lottery? The Market in Public Lands and the Regional Differentiation of Territory on the Georgia Frontier." Journal of Economic History 51: 835-860.

Weiss, Thomas (1987). “The Farm Labor Force by Region, 1820-1860: Revised Estimates and Implications for Growth.” National Bureau of Economic Research Working Paper No. 2438. Cambridge, MA: National Bureau of Economic Research.

Whartenby, Franklee Gilbert (1977). Land and Labor Productivity in United States Cotton Production, 1800-1840. New York: Arno Press.

Woodbury, Levi J. (1836). “Tables and Notes on the Cultivation, Manufacture, and Foreign Trade of Cotton.” Executive Documents, 4, no. 146 (March 4), 24th Congress, 1st Session. 
Wright, Gavin (1976). "Prosperity, Progress, and American Slavery." In Reckoning with Slavery: A Critical Study in the Quantitative History of American Negro Slavery, edited by Paul A. David, Herbert G. Gutman, Richard Sutch, and Peter Temin. New York: Oxford University Press, pp. 307-336.

Wright, Gavin (1978). The Political Economy of the Cotton South: Households, Markets, and Wealth in the Nineteenth Century. New York: Norton.

Wright, Gavin (1979). “The Efficiency of Slavery: Another Interpretation.” American Economic Review 69: 219-226.

Wright, Gavin (1986). Old South, New South: Revolutions in the Southern Economy since the Civil War. New York: Basic Books.

Wright, Gavin (2006). Slavery and American Economic Development. Baton Rouge: Louisiana State University Press. 
Table 1: Cotton Bales per Worker (Age 10 and over) in Agricultural Labor Force in Cotton Counties, by Region, 1800-1860

400-Pound Cotton Bales per Slave (Age 10 and over)

\begin{tabular}{rrrrrrr}
\multicolumn{2}{c}{ Old South } & \multicolumn{2}{c}{ New South } & All South & New/Old & \multicolumn{2}{c}{ New South Share } \\
1800 & 1.00 & & \multicolumn{2}{c}{ Ratio } & Ag LF & Output \\
1810 & 1.15 & 2.17 & 1.04 & & 0.04 & 0.08 \\
1820 & 1.25 & 2.40 & 1.52 & 1.92 & 0.23 & 0.37 \\
1830 & 1.66 & 3.14 & 2.14 & 1.89 & 0.32 & 0.47 \\
1840 & 1.95 & 4.02 & 2.94 & 2.07 & 0.48 & 0.65 \\
1850 & 2.65 & 3.89 & 3.34 & 1.47 & 0.56 & 0.65 \\
1860 & 2.56 & 5.36 & 4.26 & 2.09 & 0.61 & 0.76
\end{tabular}

400-Pound Cotton Bales per Free Worker and Slave (Age 10 and over)

\begin{tabular}{rrrrrrr}
\multicolumn{2}{l}{ Old South } & \multicolumn{2}{c}{ New South } & All South & New/Old & \multicolumn{2}{c}{ New South Share } \\
1800 & 0.61 & & \multicolumn{2}{c}{ Ratio } & Ag LF & Output \\
1810 & 0.76 & 1.28 & 0.63 & & & \\
1820 & 0.83 & 1.37 & 0.98 & 1.64 & 0.26 & 0.08 \\
1830 & 1.12 & 1.87 & 1.38 & 1.67 & 0.35 & 0.37 \\
1840 & 1.27 & 2.67 & 1.93 & 2.10 & 0.47 & 0.65 \\
1850 & 1.80 & 2.55 & 2.22 & 1.42 & 0.57 & 0.65 \\
1860 & 1.78 & 3.49 & 2.84 & 1.96 & 0.62 & 0.76
\end{tabular}

Sources: Output based on three-year averages computed from the cotton production series from Carter et al. (2006) and the regional commercial production shares from Watkins (1908), adjusting to constant 400-pound bales. 
Table 2: County-Level Decomposition of Total Output and Output per Worker, 1840-1860

Counties Producing 1,000 Bales

Panel A:

Total 400-Pound Bales (in thousands)

\begin{tabular}{c|rrrrr}
\multicolumn{4}{c}{ Varying } & & \\
\multicolumn{1}{c}{ Bales per Worker } & & Slave Labor \\
\multicolumn{1}{c}{1840} & 1850 & 1860 & & Force (in thousands) \\
\cline { 2 - 4 } 1840 & 1,969 & 1,733 & 2,683 & & 960 \\
1850 & & 2,469 & 3,924 & & 1,152 \\
1860 & & & 5,360 & & 1,460
\end{tabular}

Varying

Slave labor

Force numbers

$$
1860
$$

\begin{tabular}{l|rrr}
\multicolumn{3}{c}{ Varying } \\
\multicolumn{3}{c}{ Bales per Worker } \\
1840 & 1850 & 1860 \\
\cline { 3 - 4 } 1840 & 2.05 & 1.80 & 2.79 \\
1850 & & 2.14 & 3.41 \\
1860 & & & 3.67
\end{tabular}

Panel B:

Average Bales per Worker

\section{Varying}

Slave labor

Force shares

Notes: The figures in plain text are actual estimates; those in italicized text are counterfactual estimates; see text. Panel A varies the slave labor force by county along the rows and the bales per worker by county across the columns. Panel B varies the county slave labor force shares along the rows, controlling for overall size of the labor force.

Source: Compiled based on county-level labor force numbers from Craig and Weiss (1998) and cotton production data from Craig, Haines, and Weiss (2000). 
Table 3: Per Capita Income before the Civil War in 1860 Prices

\begin{tabular}{|c|c|c|c|c|c|c|}
\hline \multirow[t]{2}{*}{ 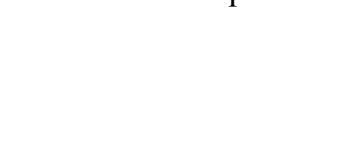 } & \multicolumn{2}{|c|}{$\begin{array}{l}\text { Total } \\
\text { Population }\end{array}$} & \multirow[b]{2}{*}{$\begin{array}{l}\text { Growth Rate } \\
\text { (Percent) }\end{array}$} & \multicolumn{2}{|c|}{$\begin{array}{l}\text { Free } \\
\text { Population }\end{array}$} & \multirow[b]{2}{*}{$\begin{array}{l}\text { Growth Rate } \\
\text { (Percent) }\end{array}$} \\
\hline & 1840 & 1860 & & 1840 & 1860 & \\
\hline National Average & $\$ 96$ & 128 & 1.44 & 109 & 144 & 1.39 \\
\hline North & 109 & 141 & 1.29 & 110 & 142 & 1.28 \\
\hline Northeast & 129 & 181 & 1.69 & 130 & 183 & 1.71 \\
\hline North Central & 65 & 89 & 1.57 & 66 & 90 & 1.55 \\
\hline South & 74 & 103 & 1.65 & 105 & 150 & 1.78 \\
\hline South Atlantic & 66 & 84 & 1.21 & 96 & 124 & 1.28 \\
\hline East South Central & 69 & 89 & 1.27 & 92 & 124 & 1.49 \\
\hline West South Central & 151 & 184 & 0.99 & 238 & 274 & 0.70 \\
\hline
\end{tabular}

Notes: "Free Population" estimates treats slaves as intermediate goods with maintenance cost of \$20 per head per year.

Source: Engerman (1967), p. 87. 
Figure 1: Picking Rate Indexes, 1801-1862

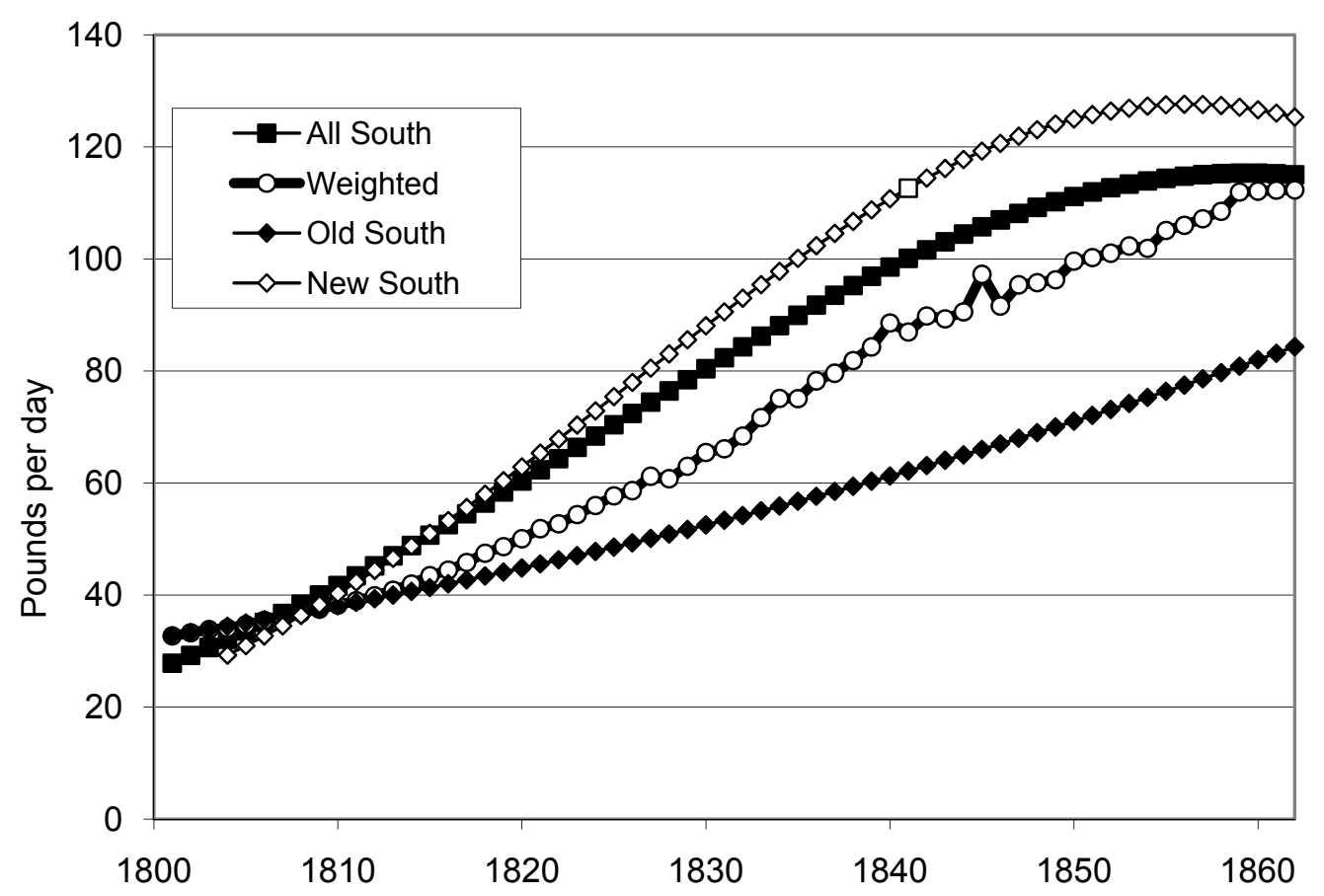

Sources: Compiled from data in Olmstead and Rhode (2008b) and Watkins (1908). 
Figure 2: Distribution of 1859 Parker-Gallman Sample by 400-lb Bales per Slave
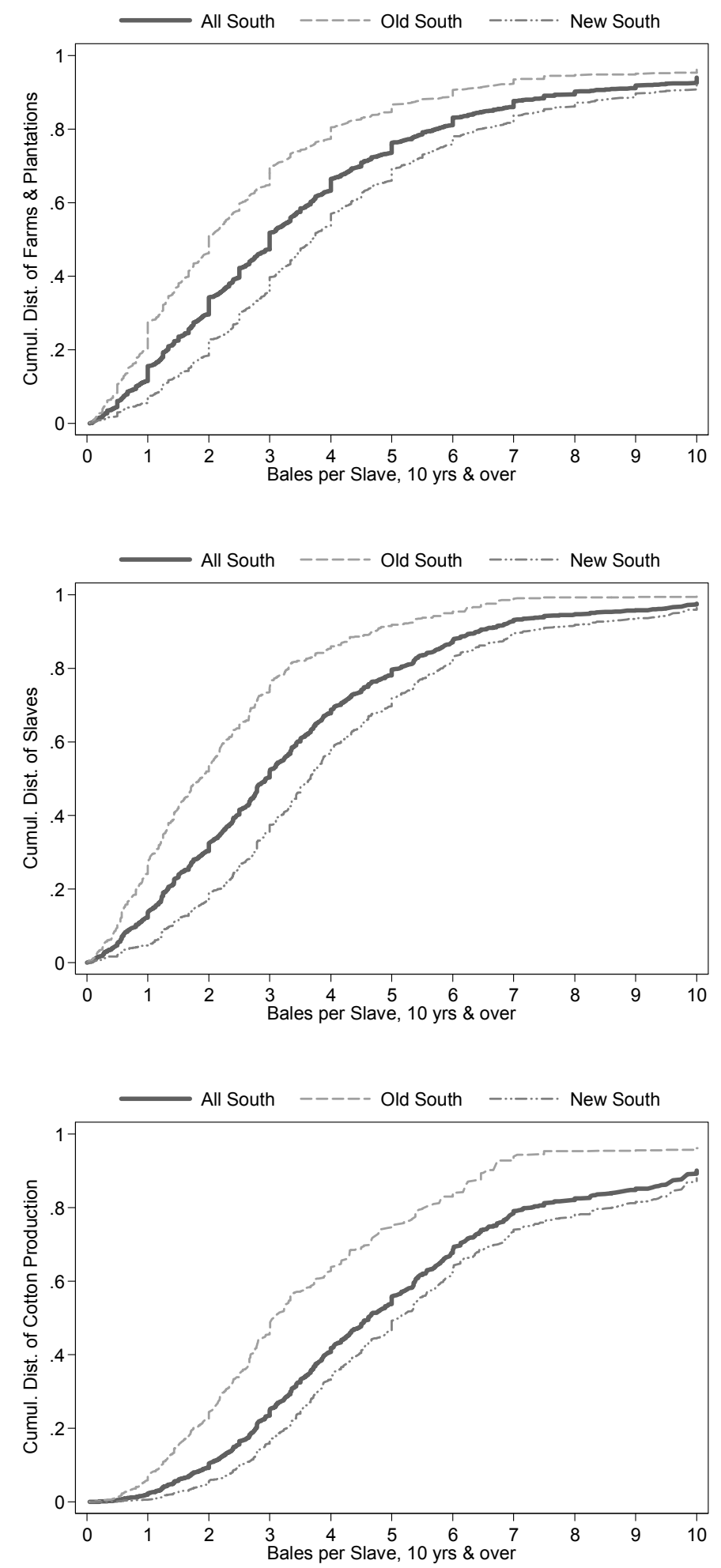

Source: Compiled from data in Parker and Gallman (1991) 
Figure 3: Panel A: 400-Pound Bales per Slave in Agricultural Labor Force

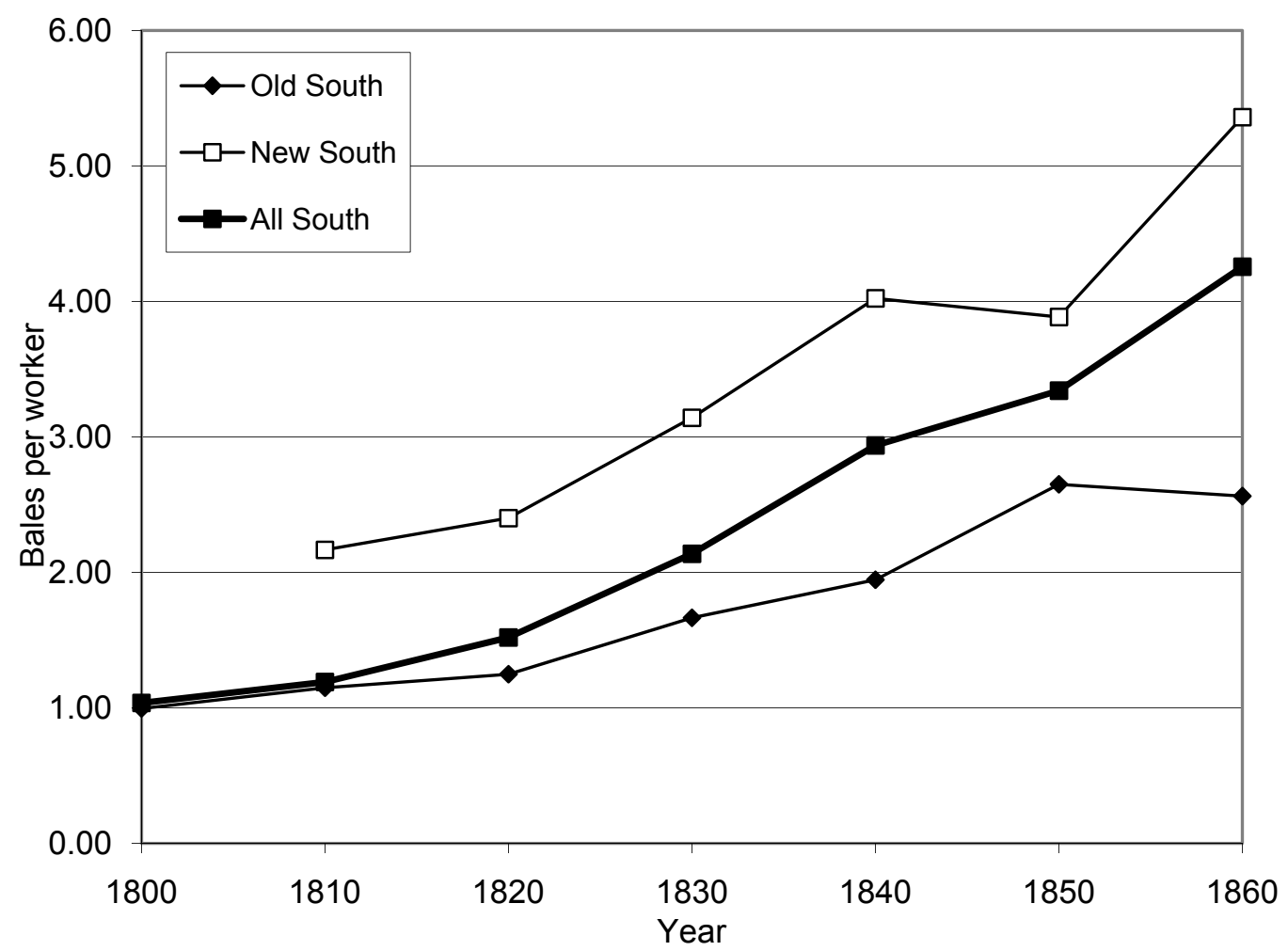

Panel B: 400-Pound Bales per Free Worker and Slave in Ag. Labor Force

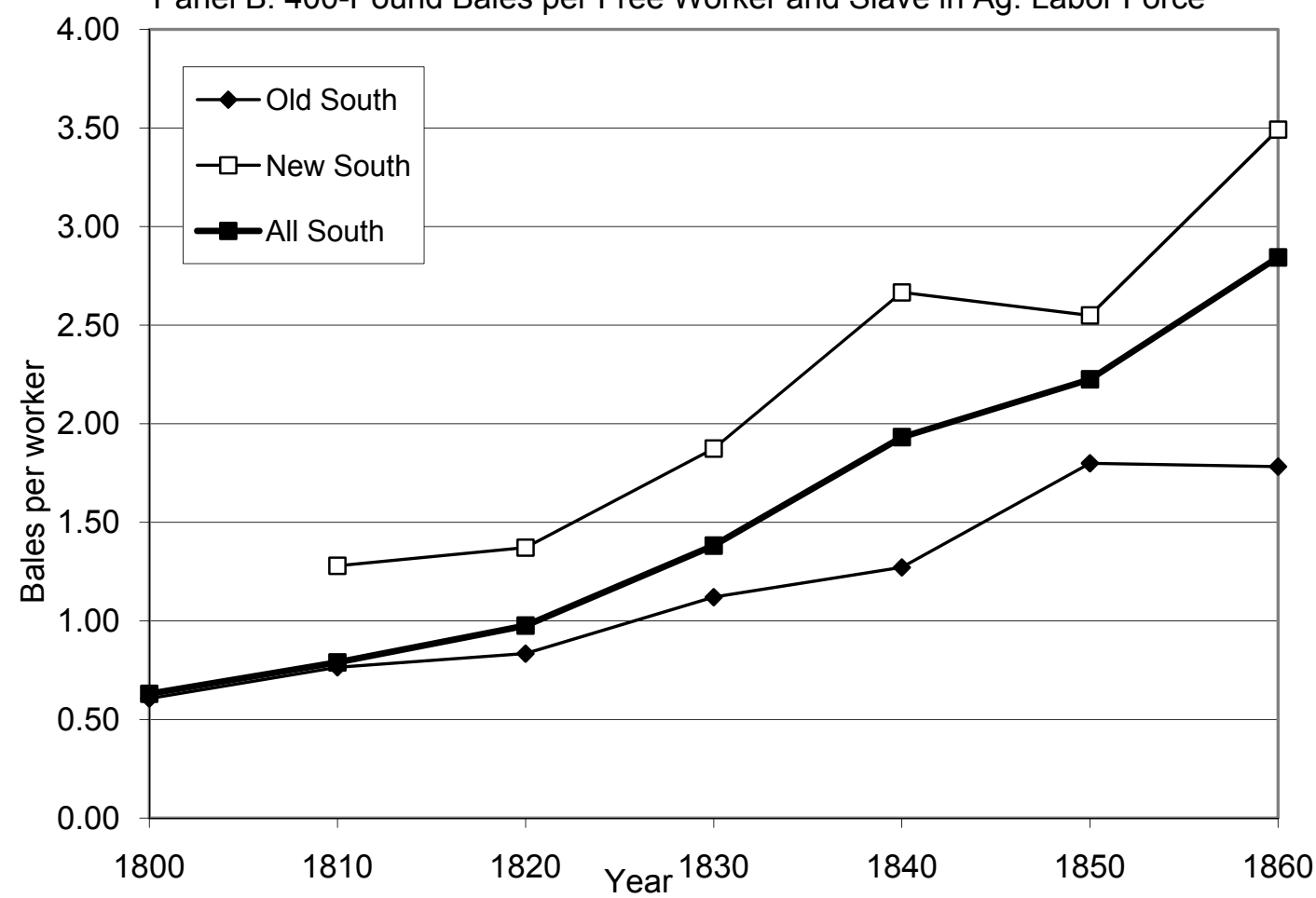

Sources: Compiled from data in Carter, et al., (2006), Craig, Weiss (1998), Watkins (1908). 
Figure 4: Output of 400-Pound Cotton Bales per Worker Slaves, 1840
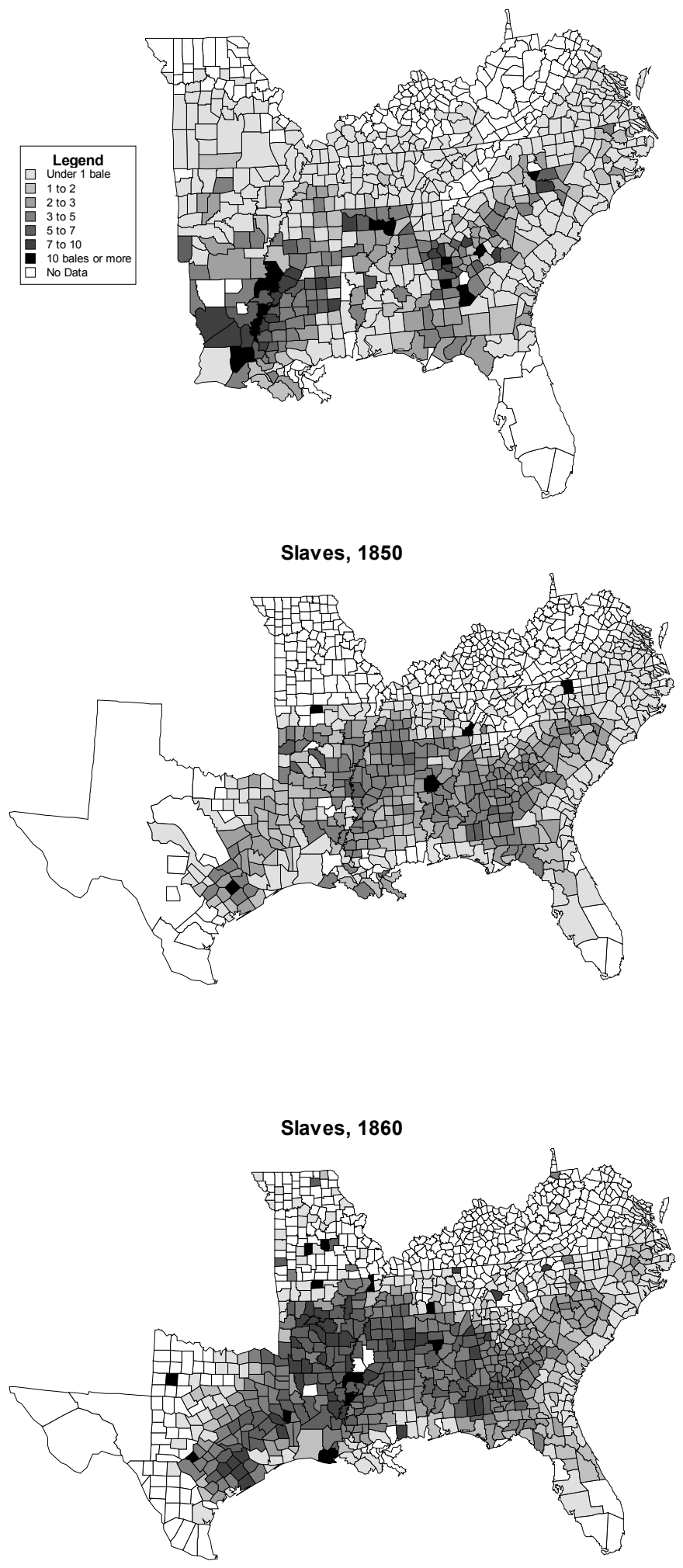

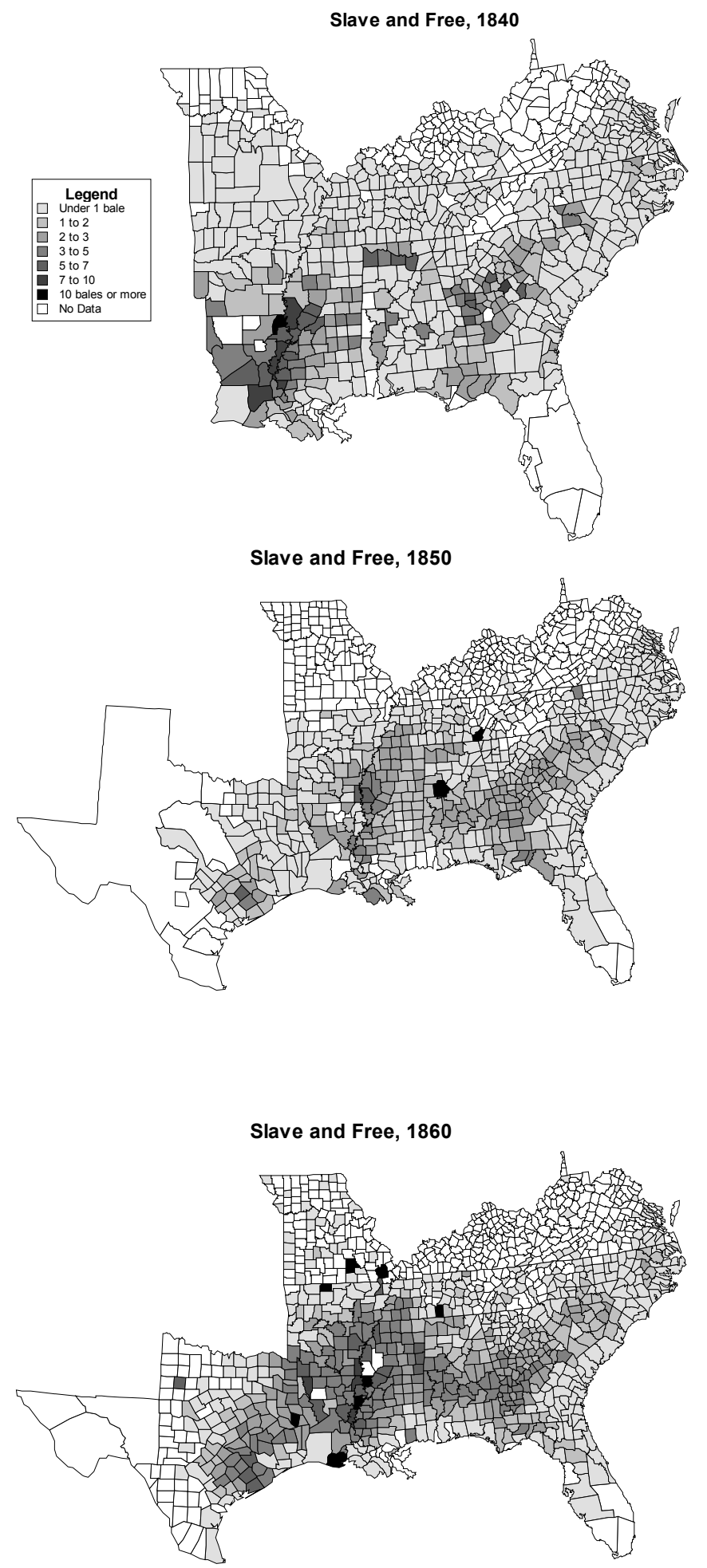

Sources: Compiled from data in Craig, Weiss (1998) and Craig, Haines, Weiss (2000). 